\title{
Technology of Pesticide Application in Corn - Nozzles, Sprays Volume, Economic Analysis and Diseases Control
}

\author{
Fernando Cezar Juliatti, Fernanda Cristina Juliatti, \\ Breno Cezar Marinho Juliatti and David S. Jaccoud-Filho
}

Additional information is available at the end of the chapter

http://dx.doi.org/10.5772/51103

\section{Introduction}

Brazil is the third largest producer, following by U.S. and China, respectively. According CONAB (2011); the annual corn production in Brazil was approximately 50 million tons in an area equivalent to 15,2 million hectares. About $45 \%$ of this area is sowed in the secondcrop season (winter), and $70 \%$ is sowed in regular (summer) season. The Brazilian corn yield (average summer and winter) is around 4,3 tons per hectare, while the U.S. average is 9.6 tons per hectare. One of the explanations is due to lower climate potential for yeld in second crop season (winter), low application technology, which turns out to be a limiting factor for achieving the crop genetic potential. In U.S., there is a more favorable climate, suitable for larger productions. However, the lack of technology investments in Brazil is presented as a major deterrent. This lack of investment reflects a serious problem, while the demand for food is increasing and areas for expansion of agriculture are being reduced.

According to Agrianual (2011), the harvest of 2010/2011 season showed that the world's leading producers of corn are: the United States (331 million tons), China (148 million tons), Brazil (50 million tons), Argentina (24 million tons) and Mexico (23 million tons), which respectively, with $42.9 \%, 19.2 \%, 6.5 \%, 3.4 \%$ and $2.9 \%$ of world production (771 million tons). Nationally, the corn area is approximately 14.640 million hectares and total production about 49.848 million tons in the 2010/2011 season, placing it among the major grain yield. In early 2000, the use of fungicides has been intensive in order to promote productive lower losses, caused by foliar diseases. Nowadays, many corn-producing regions are used to spray fungicides within their technological package. Besides the introduction of new products registered by the Ministery of Agriculture and Food Supply (MAPA), there was a significant increase in application technology, especially by the application of chemicals through 
aviation. The success of the plant protection depends largely on: identification, quantity and location of the target to be reached. The size, shape, nature of the surface and other characteristics influence on the retention of sprayed droplets (JULIATTI, NASCIMENTO, REZENDE, 2010). According to the characteristics of the target and environmental conditions, should be select the most effective equipment to reach it by finding the lowest possible pesticide waste and greater biological effect (BOLLER; FORCELLINE, 2007).

Mato Grosso is the warmest and biggest corn production state in Brazil. In this region, a technique known's as aircraft with "low volume oil" (substitution of water for another means) (Monteiro, 2003, Ozeki, 2006) has been used to reduce the sprays volume and also the drop's evaporation. This technique has been successfully used in the control of several corns' disease in different production regions.

\section{Diseases evolution on maize fields in Brazil}

From the 90's (JULIATTI et al., 2007) foliar fungal diseases had increased it's incidence and severity and causing significant qualitative and quantitative reduction in maize production. These diseases are: a white leaf spot caused by a combination of Pantoea ananatis, and fungi,

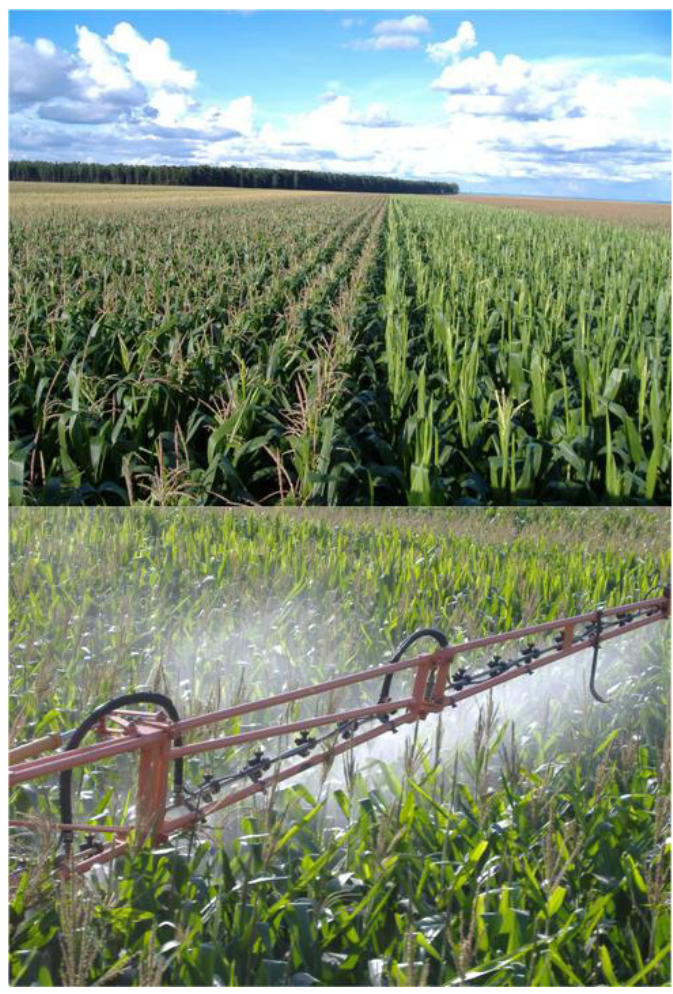

Photos. F.C. Juliatti

Figure 1. Fungicides sprays in maize after blossom starting 
Phoma sorghina and Phaeosphaeria maydis, Cercospora leaf spot (Cercospora zeaemaydis), rusts caused by Puccinia sorghi, and Puccinia polysora, Phyzopella zeae, and leaf spot by turcicum ( Exserohilum turcicum). Frequency of outbreak by Stenocarpella macrospora has been increased with high plant density, spaced by 0,45 or $0.50 \mathrm{~cm}$ between rows. In Brazil, hybrid resistance and fungicides sprays used in different stages (V6 to V8, R1 (figure 1), are the most important tools for diseases management The main diseases in these stage are: cercospora and stenocarpella leaf spot, rusts and white or phaeospaheria spot (figure 2)..

Juliatti et al 2007, studied fungicides residual in corn and established the period of control in 25-30 days. The timing of application depends on: initial inoculums and environment conditions. The hybrid response depends on: disease inoculums levels, environment conditions and genetic response (resistance level) (Figure 3). The figure 2 show the main diseases in Brazil

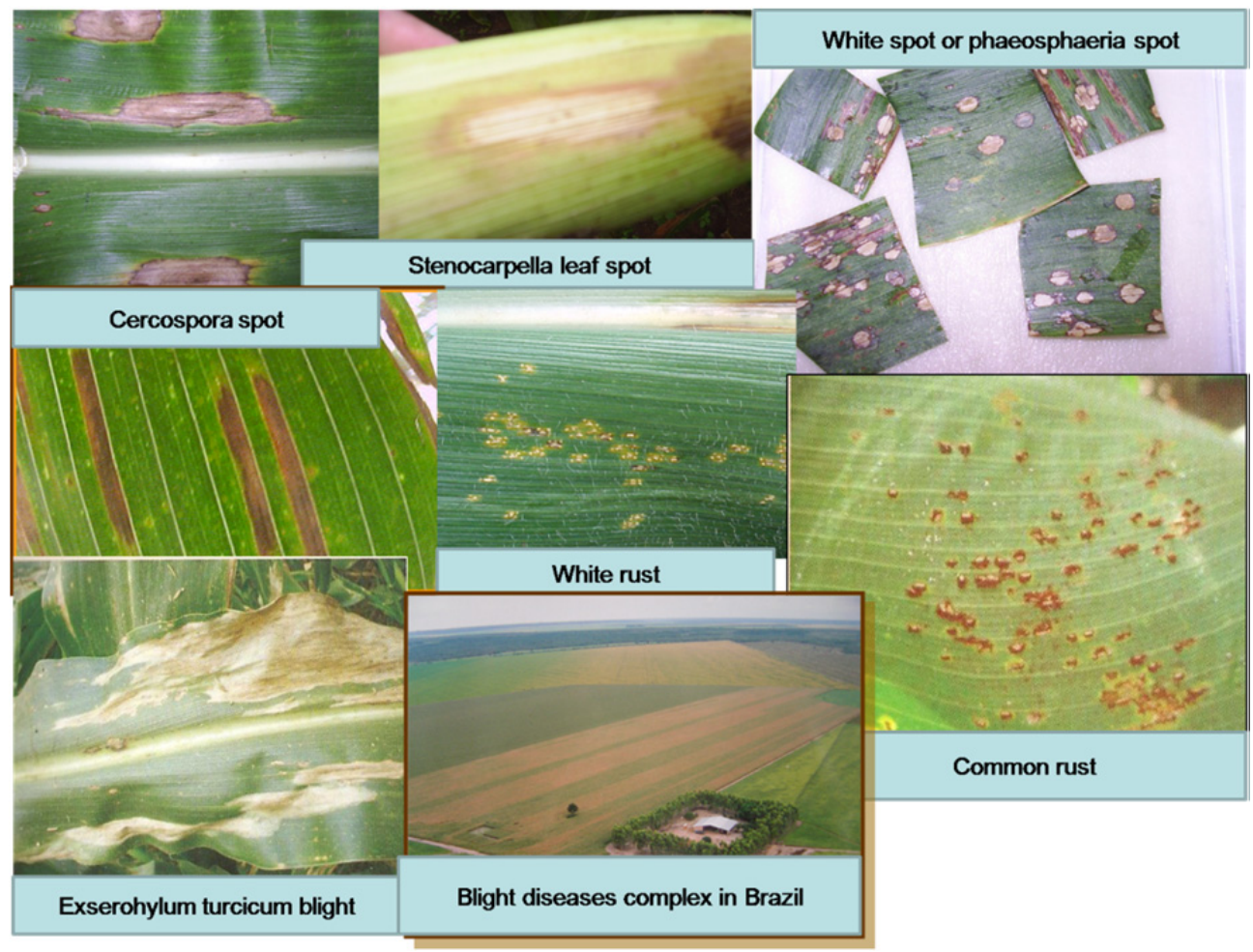

Figure 2. Mainly diseases in Brazil for fungicides spray on leaves

In 2011/2012 crop season, the majority of commercial hybrids in Brazil presented highly susceptibility to Puccinia polysora (rust), following by Exserohilum turcicum, grains healthy quality, Fusarium and Stalk rot diseases [Jaccoud Filho, 2011] (Table 1). 


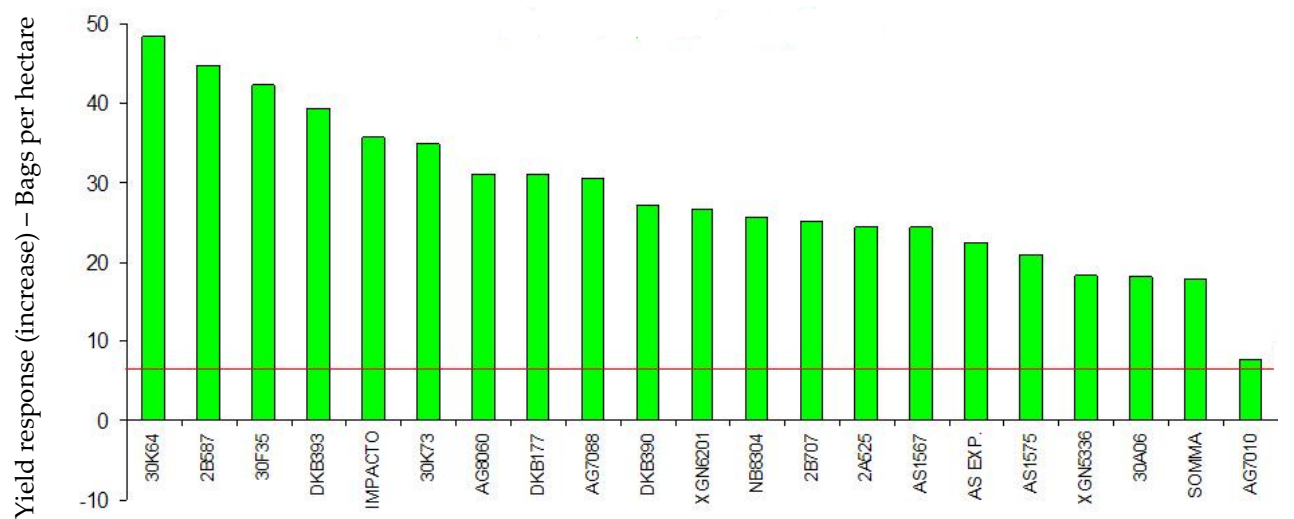

Figure 3. Hybrid response in Brazil from two sprays (V8 and R1)

\begin{tabular}{|c|r|r|r|r|r|r|}
\hline & \multicolumn{7}{|c|}{ Percentages } \\
\hline DISEASES & HS+S & MS+MR & HR+R & LT+MT & T+HT & NI \\
\hline $\begin{array}{c}\text { Fusarium xylarioides } \\
\text { Fusarium } \\
\text { graminearum }\end{array}$ & $1,63 \%$ & $31,90 \%$ & $2,45 \%$ & $17,79 \%$ & $6,33 \%$ & $39,87 \%$ \\
\hline Puccinia sorghi & $2,04 \%$ & $59,10 \%$ & $6,33 \%$ & $14,11 \%$ & $13,08 \%$ & $5,31 \%$ \\
\hline Physopella zeae & $7,15 \%$ & $40,49 \%$ & $5,93 \%$ & $14,72 \%$ & $3,47 \%$ & $27,60 \%$ \\
\hline Puccinia polysora & $17,38 \%$ & $56,23 \%$ & $5,52 \%$ & $8,17 \%$ & $8,17 \%$ & $5,11 \%$ \\
\hline $\begin{array}{c}\text { Phaeosphaeria maydis } \\
\text { and White leaf spot } \\
\text { complex }\end{array}$ & $7,15 \%$ & $59,30 \%$ & $4,49 \%$ & $13,49 \%$ & $11,65 \%$ & $3,88 \%$ \\
\hline Stunting & $7,77 \%$ & $36,40 \%$ & $5,11 \%$ & $8,38 \%$ & $13,49 \%$ & $28,83 \%$ \\
\hline H. turcicum & $2,04 \%$ & $63,80 \%$ & $3,27 \%$ & $12,47 \%$ & $12,06 \%$ & $6,33 \%$ \\
\hline H. maydis & $4,29 \%$ & $34,76 \%$ & $2,86 \%$ & $11,86 \%$ & $7,56 \%$ & $38,85 \%$ \\
\hline Cercospora zeae-maydis & $6,74 \%$ & $54,60 \%$ & $4,08 \%$ & $13,70 \%$ & $8,99 \%$ & $11,86 \%$ \\
\hline Stalk rot & $1,63 \%$ & $53,57 \%$ & $6,33 \%$ & $10,83 \%$ & $16,97 \%$ & $10,63 \%$ \\
\hline $\begin{array}{c}\text { Grains' healthy } \\
\text { quality }\end{array}$ & $2,24 \%$ & $54,39 \%$ & $8,17 \%$ & $10,83 \%$ & $16,15 \%$ & $8,17 \%$ \\
\hline
\end{tabular}

Source: Jaccoud Filho et al., 2011

Legends: HS: Highly Susceptible; S: Susceptible; MS: Moderate Susceptible; MR: Moderadate Resistant;

HR: Highly Resistant; R: Resistant; LT: Low Tolerance; MT: Moderate Tolerant; T: Tolerant; HT: Highly Tolerant;

NI: No information available.

Table 1. Susceptibility levels of commercial corn's hybrids in the crop season 2011/2012, in relation with the main pathogens and diseases.

Several factors has been contributing to the diseases incidence increase in corn: cultivated area expansion, hybrids with high differences on resistance level, inadequate management 
of water in crops under pivot irrigation, direct sowing system, row spacing reduced $(0,45-0,5$ $\mathrm{m}$ ) and low crop rotation practice, increasing the pathogens initial inoculums (PINTO et al., 1997, JULIATTI, et al. al., 2007).

According to EMBRAPA (2005), the grains can be damaged by fungi at pre-harvest (ear rot fungi with the formation of damaged kernels), during the post-harvest processing, storage and transport (musty or moldy grains). In the process of colonization of grains, many species of fungi known are toxigenic (Fusarium spp., Aspergillus spp., Penicillium spp.) The most common damages are: discoloration of grains, reductions in the contents of carbohydrates, proteins and sugars and production of toxic substances called micotoxins.

\section{Spray technology, nozzles, droplet diameter, fungicides action and disease control}

The correctly fungicides use can reduce the amount of damaged kernels combined with an appropriate spraying technology. In this context, the staff of the UFU plant, management, in partnership with the Club of Friends of the Earth (Clube amigos da Terra- CAT) in Uberlândia - MG (Growers Council from Uberlândia, Minas Gerais state), has been developing over the past six years, studies on the appropriate response of maize hybrids in relation with disease's evolution, estimates of losses, responses to fungicides (DMI's, QoIs and mixtures of QoIs and DMI's), spray technology (adjusting equipment for the best volume, aircraft and terrestrial equipments, evaluating the type ends flat fan, cone) and impact in the disease's control. Were studied volumes of ranging from 100 to 200 L.ha- $^{-1}$, for spray by self-propelled land and air ranging from 10 to 30 L.ha-1 .

The droplet diameters are one of the most important and represents a spray droplet size expressed in $(\mathrm{mm})$. It depends on the type of target, flow rate, pressure spray and equipment conditions. As the size of droplets produced in a spray is not uniform, the diameter is represented by a number, which may be the volume median diameter (DMV), or the number median diameter (DMN). The DMV is the droplet diameter that divides the spray volume into two halves, while the DMN is the droplet diameter which divides the number of drops of a spray into two halves, which are placed in ascending or descending order of size (BOLLER; FORCELINE, 2007; JULIATTI, NASCIMENTO, REZENDE, 2010). Thus, according to Boller and Forceline (2007), for application of pesticides, the ideal wind speed is between 3.2 to 6.5 $\mathrm{Km} . \mathrm{h}^{-1}$. However, the absence of winds may be associated with the occurrence of convective air currents, which can keep the drops of a finer spray suspension, leaving them susceptible to wind action. The droplet size generated by the machine depends of the spray solution properties, the type and size of the tips orifice and the pressure that the liquid is subjected to pass for their tips. The factors that makes more influence in the application technology are: target distance and environment conditions (humidity, temperature, wind speed). Is essential to control these factors to insurance the quality of application. According Forceline and Boller (2007), the air-induced droplets, is not recommended for fungicides application, because usually diseases epidemics starts on the lower plant dossel, and air induced droplets concentrate the fungicide in the middle to the top of plant dossel. Although, these technology 
generates larger droplets, that can travel the distance between the generating source and the target in less time and can settle this or suffer driftage.

Drift is one of the most serious problems that may occur during a pesticide application. The drops generated by ground sprayers, agricultural aircraft among others, can be carried by wind or air currents reaching upward causing losses and unwanted places, contaminating areas near or distant of the target, off-site sprays. Miller (2006), in the case of aerial application, the higher flying height increase the distance that the drop has to go to reach the target and the longer it will be prone to meteorological factors, thus being more prone to suffer (drift) wind action. According to Christofoletti (1996 and 1999), very fine droplets (diameters smaller than 100 microns) are still hovering in the air for a long time and may evaporate or be carried by air currents away from the biological target, making losses due to drift and contaminating the environment. The smaller the droplet diameter, the greater susceptibility to drift. The air resistance to the free fall of a drop is inversely proportional to this diameter, as can be seen in Table 2 .

\begin{tabular}{ccc}
\hline Diameter of drops $(\boldsymbol{\mu m})$ & Classification & Drift distance \\
\hline 500 & Light rain & $2 \mathrm{~m}$ \\
200 & Drizzle & $5 \mathrm{~m}$ \\
100 & Fog & $15 \mathrm{~m}$ \\
30 & Clould & $150 \mathrm{~m}$ \\
15 & Aerosol & $610 \mathrm{~m}$ \\
\hline
\end{tabular}

Source: Cristofoletti, 1999; Boller et al. 2007, Juliatti et al. 2010, Santos 2012.

Table 2. Classification of drops by size and horizontal drift distance of droplets released into free fall, the $3 \mathrm{~m}$ in height and crosswind of $5 \mathrm{~km} \mathrm{~h}^{-1}$.

As the distribution of droplets size, coming from a hydraulic power machinery, can be very heterogeneous, some of these will be more susceptible to drift, making the potential risk of drift (PRD). It is understood by the PRD, the percentage of spray volume composed of droplets smaller than 150 micron, which can be lost through drift and evaporation. International standardizing societies, as BCPC (British Council Crop Protection) and ASAE (American Society of Agricultural Engineering) established the limit of six categories of "spray quality", based on droplet size (Table 3).

\begin{tabular}{cccc}
\hline $\begin{array}{c}\text { Categories of spray } \\
\text { (Quality approximate) }\end{array}$ & $\begin{array}{c}\text { Aproximate DMV } \\
\text { (ASAE standard) }\end{array}$ & $\begin{array}{c}\text { DMV (BCPC } \\
\text { standard) }\end{array}$ & $\begin{array}{c}\text { PRD ( BCPC } \\
\text { standard) }\end{array}$ \\
\hline Very thin & $<150$ & $<119$ & $57 \%$ \\
Slim & $150-250$ & $120-216$ & $20-57 \%$ \\
Average & $250-350$ & $217-352$ & $5,7-20 \%$ \\
Thich & $350-450$ & $353-464$ & $2,9-5,7 \%$ \\
Very Thick & $450-550$ & $>464$ & $<2,9 \%$ \\
Extremely thick & $>550$ & ----- & ----- \\
\hline
\end{tabular}

Source: Adapted from Brown-Rytlewski and Staton (2006).

Table 3. Categories of drop size standards of a second spray ASAE and BCPC and potential risk of drift (PRD) and the respective sizes of the droplets. 
The table 4 presents some results in corn compared aerial and terrestrial applications in disease control. According to the results from this table, the best control of main maize diseases in the field from savanna conditions in Brazil was the terrestrial application with the combination of the 150L.ha-1 volume and the flat fan nozzle deflection double droplets. In the other hand, terrestrial application is not practicable when the crop achieve the blossom stage. In this case aerial technology is more effective. According to table 4, the aircraft technology was more effective with 15 L.ha-1 volume.

\begin{tabular}{|c|c|c|}
\hline Treatments & $\begin{array}{c}\text { White leaf spot }{ }^{*} \text { AUDPC } \\
\left({ }^{*} \text { Phaeospahaeri } a \text { leaf spot }\right)\end{array}$ & $\begin{array}{c}\text { Cercospora leaf } \\
\text { spot AUDPC }\end{array}$ \\
\hline 1 - Air (30 L ha-1) & $808.75 b$ & $242.12 b$ \\
\hline 2 - Air (15 L ha-1) & $195.75 \mathrm{a}$ & $308.75 b c$ \\
\hline $\begin{array}{l}3 \text { - Terrestrial ( } 150 \mathrm{~L} \mathrm{ha}^{-1} \text {, deflection } \\
\text { nozzles with air induction) }\end{array}$ & 257.12 a & $323.25 b c$ \\
\hline $\begin{array}{l}4 \text {-Terrestrial ( } 150 \mathrm{~L} \mathrm{ha}^{-1} \text {, the flat fan } \\
\text { nozzle deflection double) }\end{array}$ & $368.75 \mathrm{a}$ & $30.37 \mathrm{a}$ \\
\hline $\begin{array}{l}5 \text {-Terrestrial (100 } \mathrm{L} \mathrm{ha}^{-1} \text {, nozzes } \\
\text { deflection with air induction) }\end{array}$ & 220.87 a & $277.37 \mathrm{bc}$ \\
\hline $\begin{array}{l}6 \text { - Terrestrial ( } 100 \mathrm{~L} \mathrm{ha}^{-1} \text {, the flat fan } \\
\text { nozzles deflection double) }\end{array}$ & 679.37 a & $390.75 c$ \\
\hline 7 -Check (Untreated) & $1250.62 c$ & $593.75 d$ \\
\hline
\end{tabular}

Means followed by different letters in columns differ significantly at 5\% probability by $\mathrm{t}$ test (LSD). Juliatti et al 2010.

Table 4. AUDPC - area under the disease progress curve for White and Cercospora leaf spot in corn.

Cunha et al 2010, evaluated the effect of the aerial and ground application of fungicide in the control of corn diseases and in the spray deposition on the canopy. The hybrid AG7010 was used in this study and the spray was laid up on the bottom, middle and upper canopy of the crop. The disease severity and yield were evaluated after the application of the fungicide (pyraclostrobin + epoxiconazole), at the V8-V10 stage. The aerial application was accomplished with spray volumes of 15 and $30 \mathrm{~L} \mathrm{ha}^{-1}$, using flat-fan spray nozzles, and the ground one with $100 \mathrm{~L} \mathrm{ha}^{-1}$, using turbo twin flat-fan and air induction turbo flat-fan spray nozzles. An additional treatment that received no fungicide was also evaluated. The study of the deposition was achieved using water sensitive papers. It was concluded that the conventional treatments presented larger droplet density in the corn canopy; however all of the treatments provided the minimum deposition recommended for fungicide application. The aerial application using spray volume of $30 \mathrm{~L} \mathrm{ha}^{-1}$ provided similar yield to the conventional treatments, showing to be technically feasible to use. Although AUDPC and economic analysis weren't assessed in this study.

The definition of parameters such as droplet size and spray volume depends directly on the relation target/pesticide. Systemic products can be sprayed at lower droplet density, allowing the use of larger droplets.This facilities the adoption of drift reduction techniques, improving safety on spraying and increasing their operational efficacy. When used 
correctly, larger droplets assure a good deposition level (amount or volume deposited on the target), it's not necessary the best coverage.Then the results from table 4 confirmed this hypothesis and objective. By the way contact fungicides and those limited systemicity require the use the smaller droplets and or greater volumes, due to the greater dependence on better target coverage. For example, when the spray target includes the lower or inner parts of a plant, such as spraying for Cercospora leaf spot, rusts and white spot (phaeospaheria leaf spot), a good droplet penetration cloud is required an, therefore, smaller droplets should be desired.

An important characteristic for the definition of maize diseases control strategies, in relation to spray technology, is the mode of plant movement of the systemic fungicides after spraying and absorption. Most fungicides used in the fields in the market today possess leaf movement only from the base to the tip of each leaf, with minimum chance of translocation from one leaf to another. This means that, although these products are classified as systemic, application technology must provide a good coverage and penetration of the droplets through the leaf mass. In most cases, to obtain good control adequate leaf coveraged is needed, with emphasis on the lower parts of the plant, where the disease starts.

Still in the case of plant directed spraying, a study of target characteristics should include leaf movement (wind or air assistance), development stage, wax layer, hair layer, roughness, leaf surface (upper/lower) and plant architecture. These factors are fundamental for the definition of leaf droplet retention (choice of thick or fine droplets) and plant tissue penetration by the fungicide. Similarly, differences are expected on the spray technology requirements for different maize hybrids (figure 3).

The application technology is a major factor for crops success, because it determinates the correct application of pesticides. The experiment was conducted at Fazenda Mandaguari (Indianópolis-MG-Brazil). The experimental design was randomized in blocks with 13 treatments and 4 replications. The treatments were 4 points (TT, AD / D, ADIA / D, Cone Empty) and 3 volumes of solution (100, 150 and $\left.200 \mathrm{~L} \mathrm{ha}^{-1}\right)$ and the control. The objective was to develop the study of different types of nozzles and spray volume for the rational diseases control in corn. We evaluated the severity of disease, drops $\mathrm{cm}^{-2}$, \%green area, weight of 1000 grains and yield, being held in an economic analysis. Relative to Spot Stenocarpela, all treatments proved superior to the control. Nozzle ADIA received the least amount of drops $\mathrm{cm}^{-2}$ bottoms' of the plant. All treatments were superior to the control in relation to \%green area. All treatments showed an increase in 1000 grain weight compared to control treatment, showing the direct control of diseases with the grain filling. The highest yield was obtained when we used the volume of $100 \mathrm{~L} \mathrm{ha}^{-1}$ in all points evaluated. The economic analysis demonstrated the feasibility of a fungicide application to ensure sustainability of maize yield (figure 1 and table 5,6,7, 10 and 11).

The spray volume is on of fundamental parameters for spray success. The definition of spray volume depends on the type of target to be reached, required coverage, mode action of fungicide and spray technique, among others factors (table 5).In maize is very important a reduction of spray volume and increase the of fungicide concentration on the leaves (upper, 
middle and lower parts of plants - canopy) (table 5)The spray volume also affects the operational efficacy of spraying, since the time spent $n$ loading significantly changes the sprayer operational capacity (number of hectares treated per hour). Antuniassi (2006) reported average spray volume for rust or late cycle diseases control, tractor spraying can use from 100 to $300 \mathrm{~L} \mathrm{ha}^{-1}$, depending on the region. Base in the recent data(tables 5,6 and 7) growers can use 100-200 L.ha-1 to control maize disease. In airplane spraying the values for different kinds of pesticide vary, on average, from to 5 to 30 L.ha $^{-1}$. For maize diseases control the best spray volume was $15 \mathrm{~L} \mathrm{ha}^{-1}$ (Table 4). Usually spraying very small volume is done with very fine droplets, which increases the risk of losses, especially due to evaporation or drifting. In contrast large volume can cause spray saturation of leaves and dripping. In general, it is recommended that very low or ultra low volumes be sprayed with methods that control water evaporation, or even the substitution of water for another means. An example of this technique is the use of oil as a surfactant to reduce evaporation during low volume spraying. (aircraft with "low volume oil")

\begin{tabular}{|c|c|c|}
\hline Treatments & Volume (L ha' ${ }^{-1}$ ) & Nozzles \\
\hline 1 & \multirow{4}{*}{100} & AD/D 11002 \\
\hline 2 & & ADIA/D 11002 \\
\hline 3 & & TT 11002 \\
\hline 4 & & Empty Cone MAG 02 \\
\hline 5 & \multirow{4}{*}{150} & AD/D 11002 \\
\hline 6 & & ADIA/D 11002 \\
\hline 7 & & TT 11002 \\
\hline 8 & & Empty Cone MAG 02 \\
\hline 9 & \multirow{4}{*}{200} & $\mathrm{AD} / \mathrm{D} 11002$ \\
\hline 10 & & ADIA/D 11002 \\
\hline 11 & & TT 11002 \\
\hline 12 & & Empty Cone MAG 02 \\
\hline 13 & Untreated & --- \\
\hline
\end{tabular}

Table 5. Treatments nozzles and spray volume).

\begin{tabular}{cccc}
\hline Nozzles & Drop & Drift distance Risk & PRD \\
\hline \multirow{2}{*}{ Empty Cone MAG02 } & Very thin - Thin & Hight - Average & $\mathrm{MF}=>57 \%$ \\
& & & $\mathrm{~F}=20-57 \%$ \\
TT 11002 & Thin - Average & Average - Low & $\mathrm{F}=20-57 \%$ \\
& & $\mathrm{M}=5.7-20 \%$ \\
AD 11002 & Thin - Average & Average -Low & $\mathrm{F}=20-57 \%$ \\
ADIA 11002(“Air & & & $\mathrm{M}=5.7-20 \%$ \\
indution") & Thick - Very thick & Very Low & $\mathrm{G}=2.9-5,7 \%$ \\
\hline
\end{tabular}

* PRD=Drift risk potential

Table 6. Nozzles characteristics and drop drift distance risk classification. UFU, Uberlândia, 2007. 


\begin{tabular}{cc}
\hline Treatments & Means $^{*}$ \\
\hline Untreated (Check) & $15.94 \mathrm{~b}^{*}$ \\
TT - 100 L ha' & $4.86 \mathrm{ab}$ \\
TT - 150 L ha & $4.68 \mathrm{ab}$ \\
TT - 200 L ha & $2.46 \mathrm{a}$ \\
ADIA/D - 100 L ha-1 (“Air indution”) & $8.00 \mathrm{ab}$ \\
ADIA/D - 150 L ha & $10.32 \mathrm{ab}$ \\
ADIA/D - 200 L ha & $9.32 \mathrm{ab}$ \\
AD/D - 100 L ha & $8.32 \mathrm{ab}$ \\
AD/D - 150 L ha & $2.32 \mathrm{a}$ \\
AD/D - 200 L ha & $4.92 \mathrm{ab}$ \\
Empty Cone - 100 L ha & $4.26 \mathrm{a}$ \\
Empty Cone - 150 L ha & $3.66 \mathrm{a}$ \\
Empty Cone - 200 L ha & $5.48 \mathrm{ab}$ \\
\hline
\end{tabular}

Means followed by the same letters not are different by Tukey test by LSD $5 \%$.

Table 7. Severity of Stenocarpela leaf spot (Diplodia maydis and Diplodia macrospora) after 28 days spray in different treatments.

In the tables 8.9,10 and 10 showed the economic analyses for the maize diseases control after different spray and nozzles.

\begin{tabular}{cc}
\hline Nozzles & Means \\
\hline Empty cone (empty cone spray) & $56,33 \mathrm{a}$ \\
TT (plain spray) & $47,38 \mathrm{ab}$ \\
AD (plain spray) & $24,88 \mathrm{ab}$ \\
ADIA (plain air induction) & $21,22 \mathrm{~b}$ \\
\hline
\end{tabular}

*Means followed by the same letters not are different by Tukey test by LSD $5 \%$.

Table 8. Means of number drops in the leaves from lowest of maize plants

Another important parameter for a good spraying is droplet density, generally expressed as drops. $\mathrm{cm}^{-2}$ (table 8 ). The efficacy of a greater or lower droplet density is related to mode of action of the pesticide (systemic, contact, etc.). For fungicides spray Matthews (2000) recommended 30 to 70 , herbicide (20 to 40 ) and insecticide (20 to 30). In this case Empty cone (empty cone spray) and TT (plain spray) showed the best values (table 8).

The droplet size class affects the ability of a spraying to cover the target (figure 1). And penetrate through the canopy. Smaller droplets have better coverage capacity (empty cone, table 8) (offer greater number of droplets $/ \mathrm{cm}^{2}$ ), as well as better penetration are 
required. However, small droplets can be more sensitive to evaporation and drift processes. Thick droplets are preferred in the soybean production system for spraying herbicides with major systemic action, which are used for dessecation, such as glyphosate, while fine droplets are more used for insecticides and fungicides. The same response it's true in maize fields.

Adequate droplet size is very important for a good fungicides deposition on the target, and at the same time, avoid drift losses. Each type of nozzle produces a spectrum of droplet sizes, depending on operational pressure. Fine or thick droplets have different capacities for each spraying situation, as illustrated on the tables 5, 6,7 and 8 .

\begin{tabular}{|c|c|c|c|}
\hline Treatments* & LHA- Green leaves (\%) & $\begin{array}{c}\text { Grain storage - } \\
\text { Heavy of } 1000 \\
\text { grains(g) }\end{array}$ & Yield (sc ha-1) \\
\hline Testemunha & $40.32 \mathrm{~b}$ & $280.35 \mathrm{~b}$ & $136.3 \mathrm{~b}$ \\
\hline TT - 100 L.ha ${ }^{-1}$ & $63.34 \mathrm{a}$ & $321.25 \mathrm{a}$ & $171.6 \mathrm{a}$ \\
\hline TT - 150 L.ha $^{-1}$ & $59.66 \mathrm{ab}$ & $304.20 \mathrm{ab}$ & $153.2 \mathrm{ab}$ \\
\hline TT - 200 L.ha $^{-1}$ & $64.66 \mathrm{a}$ & $317.45 \mathrm{ab}$ & $152.5 \mathrm{ab}$ \\
\hline ADIA/D - 100 L.ha-1 $^{-1}$ & $56.66 \mathrm{ab}$ & $314.35 \mathrm{ab}$ & $153.0 \mathrm{ab}$ \\
\hline ADIA/D - 150 L.ha-1 $^{-1}$ & $54.00 \mathrm{ab}$ & $295.25 a b$ & $142.8 \mathrm{ab}$ \\
\hline ADIA/D - 200 L.ha-1 $^{-1}$ & $58.00 \mathrm{ab}$ & $302.85 \mathrm{ab}$ & $145.1 \mathrm{ab}$ \\
\hline AD/D - 100 L.ha $^{-1}$ & $60.32 \mathrm{a}$ & 322.90 a & $167.1 \mathrm{ab}$ \\
\hline AD/D - 150 L. ha ${ }^{-1}$ & $60.32 \mathrm{a}$ & $310.30 \mathrm{ab}$ & $146.7 \mathrm{ab}$ \\
\hline AD/D - 200 L. ha-1 & $56.00 \mathrm{ab}$ & $298.25 \mathrm{ab}$ & $145.8 \mathrm{ab}$ \\
\hline $\begin{array}{l}\text { Empty Cone - } 100 \mathrm{~L} . \\
\text { ha }^{-1}\end{array}$ & $67.32 \mathrm{a}$ & $325.60 \mathrm{a}$ & $157.6 \mathrm{ab}$ \\
\hline $\begin{array}{l}\text { Empty Cone }-150 \mathrm{~L} . \\
\text { ha }^{-1}\end{array}$ & $54.66 \mathrm{ab}$ & $311.30 \mathrm{ab}$ & $155.7 \mathrm{ab}$ \\
\hline $\begin{array}{l}\text { Empty Cone - } 200 \mathrm{~L} . \\
\mathrm{ha}^{-1}\end{array}$ & $57.98 \mathrm{ab}$ & $306.70 \mathrm{ab}$ & $146.1 \mathrm{ab}$ \\
\hline
\end{tabular}

*Means followed by the same letters not are different by Tukey test by LSD $5 \%$.

Table 9. LHA - Leaf Health foliar area (\%), grain storage - One thousand grain heavy (g) and yield in bags.ha- ${ }^{-1}$ from different nozzles and volumes. 


\begin{tabular}{cccc}
\hline Source of variation & Price US\$ $(\text { Liter })^{*}$ & Dose $\left(\right.$ L.ha $\left.^{-1}\right)$ & Coast US\$. ha $^{-1}$ \\
\hline $\begin{array}{c}\text { Fungicide } \\
\text { (Azoxistrobina }+ \\
\text { Ciproconazol) } \\
\text { Maquinery operation }\end{array}$ & 100.00 & 0.3 & 30.00 \\
\hline Total & -- & -- & 6.00 \\
\hline
\end{tabular}

- Notation in 06/13/2005

Table 10. Economic analyses by hectar in relation fungicide and machinery

\begin{tabular}{|c|c|c|c|c|c|}
\hline Volume & Nozzles & $\begin{array}{c}\text { Increment in } \\
\text { bags }^{*}\end{array}$ & $\begin{array}{c}\text { US\$ by } \\
\text { maize bag** }\end{array}$ & $\begin{array}{l}\text { Increment in } \\
\text { US\$ - by ha }{ }^{1} \\
\text { (Two sprays } \\
\text { R1 and R3) }\end{array}$ & $\begin{array}{c}\text { Net Return - } \\
\text { Superavit (US\$ } \\
\text { ha-1) }^{-1}\end{array}$ \\
\hline \multirow{4}{*}{$100 \mathrm{~L} \mathrm{ha}^{-1}$} & TT & 35.3 & 10.00 & 364.45 & 353 \\
\hline & $\mathrm{AD}$ & 308 & 10.00 & 317.62 & 308 \\
\hline & ADIA & 16.6 & 10.00 & 171.19 & 166 \\
\hline & Empty Cone & $2 ., 3$ & 10.00 & 219.65 & 213 \\
\hline \multirow{4}{*}{$150 \mathrm{~L} \mathrm{ha}^{-1}$} & $\mathrm{TT}$ & 16.9 & 10.00 & 174.28 & 169 \\
\hline & $\mathrm{AD}$ & 10.4 & 10.00 & 107.25 & 104 \\
\hline & ADIA & 6.5 & 10.00 & 67.03 & 65 \\
\hline & Empty Cone & 19.3 & 10.00 & 199.03 & 193 \\
\hline \multirow{4}{*}{$200 \mathrm{~L} \mathrm{ha}^{-1}$} & $\mathrm{TT}$ & 16.1 & 10.00 & 166.03 & 161 \\
\hline & $\mathrm{AD}$ & 9.4 & 10.00 & 96.94 & 94 \\
\hline & ADIA & 8.7 & 10.00 & 87.72 & 87 \\
\hline & Empty Cone & 9.8 & 10.00 & 101.06 & 98 \\
\hline
\end{tabular}

** Bags of $60 \mathrm{~kg}$ in notation at 06/13/2005 - Uberlandia board of trade

* Increment $=$ Maize bags.ha ${ }^{-1}$ in relation the untreated $($ Check $)-$ Net Yield

Table 11. Net return or superavit after economic analyses by héctar in relation fungicide and maquinery. 
It is important to highlight that even when a nozzle producing mostly thick droplets is used, a fraction of the volume sprayed will be formed by fine droplets (sensitive to drift process). This means that a given nozzle does not produce all droplets of the same size, but in a range of droplet sizes (known as spraying spectrum). For a given nozzle, the greater the percentage of fine droplets taking part of the spectrum, the greater the drift risk. This concept has bean used in several countries to standardize a ne $\mathrm{w}$ nozzle classification, in which the "drift risk" is evaluated. This classification is based in a comparison of the drift reduction percentage of the nozzle evaluated with that of a standard nozzle. In the countries where this concept was implemented (mostly Europe), some pesticides have a package label recommendation for the type of nozzle to be used, as a function of its drift reduction potential.

\section{Environmental conditions}

Besides the spray volume another fundamental parameter for treatment success is the adaptation of the technology to the environmental conditions at the spraying time. In most cases spraying should be avoided when air relative humidity is below $50 \%$ and air temperature is above $30^{\circ} \mathrm{C}$. In the presence of wind, it is ideal that spraying should be done at wind speed between 3 and $10 \mathrm{Km} \cdot \mathrm{ha}^{-1}$. The lack of wind also could be harmful, since there is a chance of ascending hot air, hindering the deposition of small droplets.

Early in the morning, late afternoon or in the evening, when air relative humidity is higher and temperature lower, are considered more adequate for spraying. From a practical standpoint, it is possible and advisable to use fine droplets at these times table 3 - DMV 150 - 250).However, it is necessary to monitor environmental conditions throught the day, for in the case of a considerable rise temperature (with a drop of air moisture), the droplet pattern needs to be changed (using larger droplets).In this case, the spray volume should be incresead to avoid a negative effect on target overage. Rainfall and dew are weather factors that also require attention when planning spraying. In the case of rainfall, care should be taken on noting the minimum time interval between spraying and rainfall, providing the minimum time interval between spraying and rainfall, providing the minimum time required for production action. In the case of dew, the presence of water in the leaves during spraying at night (dawn) and/or early I the morning can interfere on spraying technique. In such case, problems can be found either by product dilution or by eventual dripping, due to excess water and the action of surfactants in the spray mixture. However, there are situations, depending on the technique used and type of pesticide used, where dew can be beneficial. A night spraying should also consider the existence of technical limitations in relation to the pesticides, such as efficacy and absorption speed in the absence of light or low temperatures.

\section{Spray surfactants}

The use of spray surfactants has become very popular despite the little knowledge about the function of each type of substance. Listed below are the most commonly used surfactants, 
according to some of their expected functions: oils (vegetable or mineral) - reducing evaporation and easing penetration, urea - absorption, ammonium sulfate ( $\mathrm{pH}$ adjustment), spreaders (increasing contact area), adhesives (increasing product adhesion to the plants), chelating (reduce ion reactivity, facilitating the joint spray of foliar fertilizers and/or use of hard water), dispersers (reducing settling); moisturizers - reduce evaporation, emulsifiers (facilitates mixing) and drift reducers (some thickeners decrease the formulation of very small droplets). Most of the problems related to the use of surfactants in tank mixtures come from the lack of knowledge of their mode action and the implication of their use. As an example, the process of droplet formation from the nozzle can be significantly altered by a change on mixture physical characteristics, especially by the use of some formulations and by adding surfactants.Thus, basic factors as droplet size and spectrum can be altered in a more significant way by varying the mixture than by changing spray nozzles. Therefore, the use of surfactants should be preceded by a rigorous study of the real needs of the spraying system. Butler-Ellis (2004) characterized the process of droplet formation for a plane jet nozzle with the use of surfactants. The author considered the change in shape of the liquid film during droplet formation of different mixtures under the same conditions of spray pressure and outflow. These characteristics affect the final size of generated droplets. In this case, the use of an emulsion led to the increase on droplet size, with an opposite effect of spraying with surfactant.

\section{Tractorized spraying, airborne for maize diseases control}

The use of different droplet sizes and mixture volumes can result in situations with greater or lesser leaf coverage, potentially affecting fungicide performance on control. Table 2 to 11 show results of leaf surface coverage obtained with tractorized spraying in Inidianópolis, Minas Gerais state from Brazil. It was used different nozzles and droplet sizes, for each spray volume. In general, leaf coverage level was affected by droplet size, with lower coverage intensities for very thick droplets produced by air induction nozzles. This characteristic was more important when the leaf evaluated was on the lower part of the plant, where significant differences were found. In the case of very fine droplets there was a trend of better coverage for hollow cone jet, although there were no differences in comparison with double flat and flat nozzles.

In general the results obtained indicate that for situations where greater droplet coverage and penetration are fundamental for spraying success, typical of maize diseases control, air induction nozzles should be avoided and those forming fine or very fine droplets should be preferred. Among these nozzles, a clear trend of better coverage and penetration performance for the hollow cone jets was observed. However, it is important to note that this study Was done on normal weather conditions for spraying (temperature, air humidity and wind speed within the maximum recommended limits).In the case of spraying under less favorable weather conditions, the use of very fine droplets should be avoided due the great risk of drift or evaporation., and nozzles producing fine or medium droplets should be preferred. If somewhat larger droplets are used, the coverage potential can be 
compensated by an increase in spray volume. It is important to remember, still, that leaf coverage values observed in the medium and lower thirds of the plants indicate a need for attention about coverage differences generated by different nozzles (or droplet standards), since these differences can have a greater or lesser meaning depending on the type of disease and fungicide used for its control. Still in the case of tractorized spraying, several new technologies are becoming available. The use of low volume became popular, specially with rotation disk atomizers, using volumes as low as 25 L.ha $^{-1}$ with additional of oil in the mixture. Although the existing research is not enough to safely base maize diseases control, field data made available by several users indicate that such a system has good performance. On the same line as low volume spraying is the use of the electrostatic system, which has also become an option for spraying. About 20 L.ha $^{-1}$. Other technologies such as bars with air assistance and the use of nozzles with angulations relative to machinery movement, also have been evaluated for their potential for maize diseases control.

\section{Airborne $X$ tractorized application}

The increasing demand for quick and effective spraying is one of the major characteristics of the agricultural market nowadays, considering the importance of the spraying time on the success of maize diseases control. Therefore, there is an especial interest on airborne spraying (table 4).Similarly to tractorized sprayers; there are several technologies available for airplane spraying. The conventional systems (flat or conical jet nozzles) are used to spray

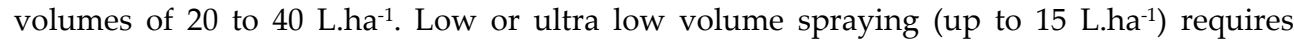
electrostatic systems (Spectrum) and rotative atomizers (Micronair, Turboero, etc.). A good part of these reduced volumes spraying is done with surfactants, such as oils (vegetable or mineral) to reduce droplet evaporation and improve product absorption.

Airborne spraying is an activity that demands important investment on system management. Even if the spraying technology choice is correct, several others factors are extremely important for success on phytosanitary control. Factors as flight height, work width, wind position, temperature and moisture and navigation systems (GPS). Usually, applying larger volumes without adding oil, demands lowers flights (about $3 \mathrm{~m}$ high), while spraying low or ultra low volumes (with oil) require higher flights (5 meters, for example). Similarity, the work width has to be adjusted for each case. Spraying with volumes between 20 and 40 L.ha $^{-1}$ employ widths of 15 meters, while spraying with lower volumes use widths larger than 20 meters. Wind position is one of the most important factors to assure good coverage of spraying bands. The airplane should always be positioned across the predominant wind, favoring band coverage. In contrast, a narrowing of the spraying bands can occur, as a super positioning error and control failure. Another important factor of airplane navigation system reports (GPS), to detect eventual failures of sprayed bands. Finally, air temperature and relative humidity should be adequate at spraying time to reduce risks of loss and drift. In airborne spraying with low volume and oil added (LVO, for example), special care should be taken to avoid working during high 
temperature and lack of wind, avoiding convective currents that hinder droplet deposition on the culture and considerably increase risk of failure and drift. Summarizing in management terms, the decision by airborne or tractorized spraying should be take several factors into account. Among the major ones are the operational capacity (number of hectares per hour), the cost per treated hectare (table 10 and 11), the predominant weather conditions, availability of service in the area, eventual regional traditions (some regions use tractorized or airborne by tradition) and the potential for mechanical damage to the culture (some authors estimate up to $3 \%$ losses by culture lodging in the case of tractorized spraying at the end of maize cycle.

\section{Conclusion}

When we look Brazil maize yield some years ago (less than 3,000 Kg.ha-1), fungicides were not necessary but, nowadays, if we consider a range of growers harvesting more than 10,000 $\mathrm{Kg}_{\mathrm{ha}}{ }^{-1}$, the use of fungicides and spray technology is essential to improve grain production. DMI and strobilurins and DMI plus strobilurins fungicides are needed for maize production sustainability in Brazil. It happens because Brazil has a tropical pathosystem conditions and it has several polycyclic diseases (rusts, blights, cercospora leaf spot or GLS, stem rot, ears rot, bacterial blight, etc.).The number of sprays, and the technology cost depends on many factors, such as is leaf area, plant architecture, hybrid resistance, environmental conditions and grain diseases. However the diseases complex increases in a high speed in tropical conditions, we can observe that the problem also advances in subtropical countries in North America and Europe. In the future, Brazil experience on maize disease control can be used in the others countries in all continents.

\section{Author details}

Fernando Cezar Juliatti, Fernanda Cristina Juliatti and Breno Cezar Marinho Juliatti LAMIP-Laboratório de Micologia e Proteção de Plantas, Instituto de Ciências Agrárias, UFU, Uberlândia, MG State-Brazil, Brazil

David S. Jaccoud-Filho

UEPG- Universidade Estadual de Ponta Grossa, Campus Universitário, Ponta Grossa, PR State-Brazil, Brazil

\section{Acknowledgement}

CAT - Uberlandia Agricultural Council for field researcher and farm tests realized in many farmers and growers.

\section{References}

[1] Agranual (2011). Anuário estatístico da agricultura do Brasil. Milho, FNP. 
[2] Antuniassi, U. R. (2006). Application technology for the control of soybean asian rust. In: Juliatti, F.C. (organizer). Soybean asian rust: etiology, epidemiology and management. P. 275-303, Edufu, UFU, 316 p.

[3] Butler-Ellis, C. (2004). The effect of spray liquid on the application of pesticide sprays.In: Qualidade em tecnologia de aplicação.Raetano, C.G.; Antuniassi, U.R. (orgs.), Botucatu-/SP, FEPAE, v.1, p.167-176.

[4] CONAB 2011. Indicadores da agropecuária. Brasília, DF.. Disponível em: http://www.conab.gov.br. Acesso em 21 nov.

[5] Boller, W.; Forcelini, C. A.; Hoffmann, L. L.(2007) Tecnologia de aplicação de fungicidas - parte I. Revisão Anual de Patologia de Plantas, Passo Fundo, v.15, p.243-276.

[6] Costa, D.I.; Boller W. (2008). Aerial and ground applications of fungicide for the control of leaf diseases in maize crop (Zea mays L.). .).In: CIGR - International Conference of Agricultural Engineering, XXXVII Congresso Brasileiro de Engenharia Agrícola,Access http://www.terraaviacao.com.br/Fungic.pdf, in 26/03/2012.

[7] Brown-Rytlewski,D.; Saton, M. (2007). Fungicide application technology for soybean rust 2006. Michigan State University - Field Crop Advisory Alert. Disponível em: www.ipm.msu.edu/cat06field/pdf/sbr_aptechnology. Pdf. Acessado em: 15/05/2007.

[8] Christofoletti, J.C. (1999). Considerações sobre tecnologia de aplicação de defensivos agrícolas. São Paulo: Teejet, 15p.

[9] Christofoletti, J. C. (1996). Considerações sobre tecnologia de aplicação. In: Guedes, J C. Tecnologia e segurança na aplicação de produtos fitossanitários: curso de atualização. Santa Maria: Departamento de Defesa Fitossanitária/ Sociedade de Agronomia. p.8-12.

[10] Cunha, J.P.A.R.;Silva, L.L.;Boller, W.; Rodrigues, J.F. (2010).Aplicação aérea e terrestre de fungicida para o controle de doenças do milho. Revista Ciência Agronômica,v.41, n.3,p.366-372.

[11] Cunha, J.P.;Pereira, R.G. (2009).Efeito de pontas e volume de pulverização no controle químico de doenças na cultura do milho.Revista Ciências Agronômicas, Fortaleza, v.40, n.4, p.533-538

[12] Fancelli, A.L.; Dourado-Neto, D. 2003. Milho: estratégias de manejo para alta produtividade. Piracicaba: ESALQ/USP, 208p.

[13] Jaccoud Filho, D. (2011). Estratégias de Manejo e Controle de Doenças na cultura do Milho. Ponta Grossa: UEPG.

[14] Juliatti, F.C.; Brandão, A.M; Santos, J.A,; Luz, W..C. (2007). Fungicidas na parte aérea da cultura do milho: evolução de doenças fúngicas, perdas, resposta de híbridos e melhoria da qualidade de produção. Revisão Anual de Patologia de Plantas, Passo Fundo, v.15, p.277-334..

[15] Juliatti, F.C.;Nascimento C.;Rezendea, A. A. (2010). Avaliação de diferentes pontas e volumes de pulverização na aplicação de fungicida na cultura do milho.Summa Phytopathologica, v.36, n.3,p.216-2221.

[16] Matthews, G.A. (2000). Pesticide application methods. $3^{\text {rd }}$ ed., Oxford:Blackwell Science.432p.

[17] Monteiro, M.V.(2003). Compêndio de Aviação Agrícola. Sorocaba- Editora Cidade, 295p.

[18] Ozeki, Y. (2006). Manual de Aplicação aérea. São Paulo, 101p. 
[19] Santos, J,M.F.dos. (2012).Tecnologia de aplicação de defensivos> Disponível em : htpp//www.biologico.sp.gov.:BR/rifib/IIIRifib/109-116.pdf.Acesso:17 março. 